\title{
As duas vidas de uma transclasse
}

\section{Ida Lucia Machado}

Docente da Universidade Federal de Minas Gerais (UFMG), Brasil. Bolsista de Pesquisa CNPq, processo 301999/2018-0. idaluz@hotmail.fr

Resumo: Este artigo desvela o tema de nossa pesquisa recém-iniciada no CNPq, na qual trabalhamos a análise do discurso versus a narrativa de vida de seres considerados como "transclasses" (JAQUET, 2015), ou seja, aqueles que passam por uma grande mudança de vida e devem enfrentar o difícil processo de fusão/transformação de identidades. Tomamos por base a obra Nunca deixe de acreditar (RICKHARDSSON, 2017) por julgarmos que ela retrata a vida de um desses seres. Visando uma melhor compreensão do leitor, resumimos a narrativa de vida contida na referida obra e destacamos alguns excertos que focalizam o modo pelo qual a narradora gerencia suas emoções, analisando-os por meio de categorias vindas de uma análise do discurso que se abre para a argumentação. Nosso objetivo foi o de mostrar um possível interpretativo de narrativas de vida e introduzir, ainda que rapidamente, a noção de "transclasse".

Palavras-chave: Narrativas de vida. Transclasse. Análise do discurso.

\begin{abstract}
This article unveils the theme of our research, recently started at CNPq, in which we work on discourse analysis versus lifestories from people considered "transclasses" (JAQUET, 2015), that is, those who undergo a major life changement and must face the difficult process of merging/transforming identities. We chose the book Nunca deixe de acreditar (RICKHARDSSON, 2017), because we think it portrays the life of one of these humain beings. To make it easier for the reader, we summarized the lifestory contained in the book and highlighted some excerpts that focus on the way the narrator manages her emotions, analyzing them with categories from a discourse analysis that opens up to argumentation. Our goal was to point out a possible interpretation of lifestories and introduce, even briefly, the notion of "transclass".
\end{abstract}

Keywords: Lifestories. Transclass. Discourse analysis. 
L'expérience narrative? C'est cela qui enveloppe et vient coudre chaque instant, chaque emplacement, chaque distraction même. (FAYE, 2010)

\section{Introdução}

Gostaríamos, neste artigo, de apresentar uma pequena parcela de nossa nova pesquisa aprovada pelo CNPq na qual, de modo geral, tomaremos como objeto de estudo pessoas que a vida transformou em "transclasses", isto é, em indivíduos que, por motivos diversos, passam de uma classe a outra, adotando um novo modo de viver e de ser. O neologismo "transclasse" foi criado pela filósofa francesa Jaquet (2015) para indicar os seres cujas vidas passam por processos radicais de mudança: de país, de profissão, de identidade, de gênero, de classe social etc., sendo que tais mudanças podem ser ocasionadas por diversos fatores.

Como sempre, nossos escritos recorrem a ideias vindas de Charaudeau (1983, 1992, 2019), mais especificamente, à sua concepção de análise do discurso na qual inserimos noções vindas de teóricos ligados à retórica e argumentação, à sociologia e à filosofia, entre outros (MACHADO, 2016). Fruto da supracitada pesquisa, nosso artigo busca trazer à luz certos dados que marcam o mergulho no passado da narradora de um livro no qual conta sua dupla vida, deixando visível, na escrita, os esforços que fez para reconstituir seu "eu" dividido. Acreditamos que o relato de si ou a narrativa de vida deve ser considerado(a) como um instrumento que ajuda a construir a história: em primeiro lugar, a pequena história, aquela que é individual e que pertence a um dado ser; em segundo lugar, a grande História, na qual esse alguém-que-senarra está inserido, ao relatar seus caminhos e descaminhos. A narrativa de vida aparece, assim, como um modo de reconstruir o passado para melhor suportá-lo e para melhor entender o presente e, a partir daí (em alguns casos), encarar o futuro com mais determinação ou serenidade. Porém, é preciso ressaltar que, nessa escrita, as noções temporais se embaralham bastante. Por isso mesmo, fazemos nossas as palavras de um personagem feminino de um 
dos filmes do cineasta francês Claude Chabrol: "O tempo é um presente eterno". ${ }^{1}$

A pergunta maior que motiva o artigo poderia ser assim formulada: “Em casos dessa natureza, como é que o narrador ou narradora deve/pode escrever para convencer o outro, o leitor, da veracidade sobre si mesmo(a), do seu esforço para reunir fatos vividos e transmitir as emoções que eles suscitaram?" Ora, examinados discursivamente, os relatos de vida consignados por escrito apoiam-se em estratégias discursivas, próprias da narratividade. Tais estratégias ganham força graças ao jogo que os sujeitos narradores realizam ao penetrar na trama temporal do ser-que-se-conta.

Para melhor compreensão do que aqui propomos, na primeira seção do artigo apresentamos, de modo panorâmico, a história de vida de uma menina de rua brasileira que se tornou uma cidadã sueca de classe média. Para tanto, iremos nos basear na tradução para o português de uma narrativa de vida originalmente escrita em sueco por Christina Rickhardsson (2017). Em seguida, examinaremos alguns trechos desse relato em que é possível notar o trabalho realizado pela narradora - e seu duplo, já que existem duas vozes que narram: a da Christiana brasileira e a da Christina sueca. Veremos, assim, alguns dos esforços dessa dupla entidade narrativa para recuperar o "tempo perdido" como diria Proust, mas, sem nunca procurar adocicá-lo ou torná-lo menos amargo. O tema central dessa busca é a figura da mãe biológica perdida.

Após examinar alguns fragmentos do passado da narradora, iremos nos deter na argumentatividade ${ }^{2}$ que perpassa seu relato e tentar discutir certas estratégias que nos auxiliarão a perceber o difícil exercício de representar a emoção pela escrita. Daremos especial ênfase aos efeitos patêmicos, segundo Charaudeau (2000), e à escrita branca, segundo Rancière (2001).

Nosso objetivo é o de mostrar como a vida de certos transclasses os leva, forçosamente, a passar por processos identitários e como certas categorias discursivas podem ser úteis para conseguirmos fazer aflorar as emoções que uma narrativa de vida suscita. Sabemos que há muito a se dizer

\footnotetext{
1 “Le temps est un présent éternel”. Essa é a última fala da atriz Suzanne Flon, no papel de Micheline, uma senhora que sente seu passado e seus dramas familiares voltarem à tona, pois são retomados pelas ações praticadas/vividas por um jovem casal do filme La fleur du mal (2010).

${ }^{2}$ Terminologia proposta por Grácio (2016, p. 33), para falar da argumentação no âmbito do texto escrito.
} 
sobre os transclasses e sobre suas lutas na passagem que fazem de uma forma de vida a outra. Porém, para o artigo em pauta, escolhemos apenas um caso para analisar e ilustrar o conceito sobre o qual voltaremos em outros escritos.

\section{As duas identidades de um mesmo ser}

O livro que agora nos interessa e que nos transmite a história de uma transclasse foi construído de forma a captar ou a reter a atenção do leitor: ele consegue manter uma tensão constante ao alternar, habilmente, duas histórias de vida de dois tempos diversos. Uma das histórias é oriunda de um passado mais remoto e nela temos o relato de vida de uma criança de rua; a outra história é narrada pela mesma criança, mas já adulta e com outra vida, outra identidade. De todo modo, ambas as histórias e vozes narrativas se imbricam.

A obra em questão foi organizada dentro desse contínuo "vai-e-vem" passado/presente. Exercício de escrita não muito fácil, como o reconhece a narradora, que, já nas primeiras páginas de sua narrativa, confessa ter duas pessoas dentro de si: "[...] uma é a Christina de Norrland e a outra é a Christiana do Brasil. Nem sempre foi uma tarefa fácil juntar essas duas" (RICKHARDSSON, 2017, p. 6). Ao longo dessa escrita, a questão de estar ou não contando a verdade do que aconteceu volta a atormentar o eu-que-narra, o que o leva a se justificar diante do leitor: "Sei que não posso confiar em todas as minhas lembranças, mas sei também que quando somos crianças podemos ver as coisas de outro ângulo". Logo em seguida, em um movimento que reflete a angústia desse ser, aparece uma pergunta que assume o ar de um pedido de ajuda ou de inclusão/cumplicidade do leitor para o que conta: “[Será que] eu me lembro mal das coisas?" (p. 134-135).

A nosso ver, essa maneira de se expor constitui uma estratégia discursiva importante: a narradora não tem receio de deixar à mostra suas fraquezas ou lapsos de memória em seu relato. Isso dá a este uma dimensão mais humana: a memória realmente é algo que pode enganá-la, mas não somente a ela: isso acontece com todos nós.

Como já afirmamos em outros escritos (2016, 2018), é comum a aparição de lacunas na recuperação que um narrador-de-si faz de seu passado. E ele as 
preenche, de forma automática, inconsciente, com a ajuda de sua imaginação. Desse modo, a realidade de uma vida encontra-se com a ficção do que essa vida poderia ter sido. Não estamos aqui referindo-nos à ficção como uma invenção in totum de um outro "eu" narrador, mas, sim, como algo que é bem comum em todos os relatos-de-si ou nos esforços dos seres humanos para recuperar acontecimentos passados: a inclusão de uma dose de ficção que a imaginação do narrador constrói como verossímil, apropriada à sua narrativa de vida.

Vamos à história que o livro nos conta. Christiana era uma menina de rua nascida em 1983, no Brasil. Vivia com sua mãe e com seu irmão, um bebê chamado Patrique, em uma caverna de Diamantina, no mato; dormia e esmolava por vezes na rodoviária dessa cidade. Era uma criança viva e esperta, com uma imaginação fértil e, não era de todo infeliz ali, com sua mãe e seu irmãozinho, apesar da dura vida que enfrentavam. Quando a mãe resolve se mudar com os dois filhos para São Paulo, a menina é jogada no turbilhão da cidade grande e aí vai sentir, mais do que em Diamantina, o problema das diferenças de classe que os seres desfavorecidos como ela devem enfrentar face àqueles que têm maior poder econômico. Como ela mesma repete, ao longo da narrativa, pobres e negros como ela eram considerados como "ratos" ou, pior ainda, como fantasmas já que às vezes, as pessoas nem os viam. O sofrimento da menina é grande e sua lucidez também: ela teme tornar-se um ser transparente aos olhos do mundo. Ao apagamento total de seu ser, ela prefere receber atos agressivos, tais como xingamentos, empurrões e cuspidelas. No caso, tais atos representam uma estranha e triste forma de comunicação.

Quanto tempo de sua vida Christiana passa nas ruas antes de ir para o orfanato? Por volta de seis, sete longos anos. A mãe aparece/desaparece sem dar explicações, mas o amor que ela transmitiu à sua filha é muito forte e está sempre presente. Há uma frase da mãe que a encoraja nos momentos mais difíceis, de fome, de perseguição, de lutas: "Christiana, a vida é difícil e injusta muitas vezes, mas nunca fique parada. Siga sempre para a frente" (RICKARDSSON, 2017, p. 81).

Um dia, Christiana e seu irmãozinho são entregues a um orfanato em São Paulo; a mãe promete ir sempre lá para vê-los, nos dias de visita. A menina 
passa a esperar e viver em função desses dias. Porém, inesperadamente, sem que ninguém se dê ao trabalho de lhe explicar as razões, impedem sua mãe de ver os filhos, o que causa em Christiana uma revolta profunda que ela exprime agredindo fisicamente uma de suas colegas. Só bem mais tarde vai saber que a mãe tinha "problemas de cabeça" e que a diretora do orfanato tinha sido orientada para não deixá-la aproximar-se das crianças. A história de Christiana e Patrique muda de rumo no dia em que são entregues a um casal sueco, sem filhos, vindos ao Brasil especialmente para adotá-los. Não é fácil para a menina deixar seu país, nem abandonar uma grande amiga que fizera no orfanato e ser lançada, tal como uma marionete, em um universo completamente diferente do seu.

Porém... um universo onde ela não vai mais viver nas ruas, mas, sim, com uma família da classe média sueca. Para quem havia sobrevivido até então em condições deploráveis, a nova família parece ser uma família de milionários! A menina, sempre lúcida e esperta, tem um forte instinto de sobrevivência e adaptação. Isso a leva a se habituar à escola e à língua de modo relativamente rápido, apesar de alguns problemas com um colega que critica sua cor e seu cabelo curto, que lhe davam um ar de menino: o garoto sueco vai aprender a respeitá-la após ter dela apanhado, o que, surpreendentemente, para Christina (seu novo prenome) não é tomado de forma negativa por seu novo pai. Ela percebe que ali está realmente em outra sociedade, onde não é mais preciso correr ao ver um guarda, bater em colegas para ser respeitada, roubar comida etc. Christina, ao aprender o sueco em apenas dois meses na escola, esquece-se, porém, completamente, do português. Torna-se um outro ser, com uma nova identidade em todos os sentidos da palavra: mesmo seu registro de nascimento muda, pois passa da brasileira Christiana Mara Coelho à sueca Christina Rickhardsson, filha de um casal sueco. O mesmo processo ocorre com seu irmão Patrique, que se torna Patrick. Como era ainda um bebê, ele se acostuma muito rápido à nova vida. Desse modo Christina vai viver, estudar, ter amigas, sendo protegida e criada por uma mãe doce e bondosa e por um pai cuja firmeza a garota estima e admira. Mas ela não se esquece de sua mãe biológica e, por vezes, tem pesadelos, flashes de sua vida miserável no país de origem. Segundo suas próprias palavras na Introdução do livro: 
amei. É sobre as memórias de minha infância na mata, nas ruas de São Paulo, no ano que passei no orfanato e sobre o recomeço da minha vida na Suécia. Minhas memórias são difusas, mas as que guardei comigo são muito claras. Tomei muito cuidado para não perdê-las, recontando tudo a mim mesma, fazendo anotações, para tentar me lembrar da pessoa que eu era antes. Criei uma história, a minha história. Não lembro exatamente da idade que eu tinha quando tudo aconteceu, nem por quanto tempo estive no mesmo lugar. Eu era uma menina de rua. Qual o significado do tempo para uma criança de rua? Por que nós deveríamos saber alguma coisa sobre isso? Não fazíamos parte da sociedade. Não existíamos em um mundo que não tinha tempo para nós, que não se importava se teríamos ou não uma educação, nem mesmo se estávamos vivos ou mortos. (RICKARDSSON, p.5, os grifos são nossos.)

Esse trecho, que está inserido na Introdução, parece-nos ser uma espécie de prólogo-desabafo-resumo que contém um "discurso argumentante" (GRÁCIO, 2016): ele introduz o leitor na narrativa de vida de Christiana/Christina. Nos enunciados por nós grifados, vemos como ela se debateu com sua memória, os esforços que fez para conservá-la viva dentro de si. Destacamos especialmente o enunciado "Criei uma história, a minha história”. Essa afirmação corrobora o que dissemos na seção inicial deste artigo: o exercício de um ser para reconstruir uma vida passada - do modo mais lógico e correto possível - é algo realizado quase sempre de modo penoso, pois, além dos tristes acontecimentos e injustiças do passado, surgem as lacunas para quem tenta recompor sua vida, ou seja, momentos impossíveis de ser reconstituídos tal como realmente ocorreram. O que fazer então? Recorrer à ficção ou, melhor dizendo, à ficção como parte da imaginação do ser-que-narra, ou seja, a parte que lhe parecerá mais lógica ou plausível.

Ressalte-se que, de uma certa maneira, a escrita memorialista tem uma função catártica para quem dela se serve. Segundo nossa narradora

Quando leio o que escrevi, percebo que a própria escrita acabou fazendo o que eu desejava que acontecesse, me ajudando ao longo do caminho. É muito bom encerrar o projeto de escrita de um livro. Não foi nada fácil me confrontar com tantas lembranças triste. Foi ao mesmo tempo um trabalho doloroso e prazeroso, mas às vezes acho que estou lendo sobre a vida de outra pessoa. Parece impossível que eu tenha passado por tudo isso. São dois mundos completamente diferentes: ser alguém vivendo nas ruas no Brasil, sem saber como se alimentar, e depois se mudar para a Suécia, onde se joga comida fora todos os dias. (RICKHARDSSON, 2017, p. 251)

Além de destacar a função catártica de escrever sobre si, a narradora reconhece a dualidade de seu ser, quando seu relato está pronto, e se espanta 
com as grandes diferenças, com o abismo que há entre uma menina pobre brasileira e uma mulher de classe média sueca, para constatar que, afinal de contas, as duas são personagens da mesma história de vida.

Essa dupla história de vida explica a decisão de Christina, já adulta, de voltar ao Brasil, acompanhada por uma amiga sueca que falava a língua portuguesa para ajudá-la em sua empreitada de busca do passado perdido, além de assumir uma importante função prática: a de servir de tradutora para a "ex-brasileira", já que, para a narradora, como dissemos, não restou nada da língua materna ou pouca coisa: talvez uma musicalidade que os brasileiros têm ao falar, alguns sons...

Uma vez no Brasil, após ter tido o natural choque de uma sueca que se depara com uma metrópole cinza e assustadora como São Paulo, a narradora vê que há bairros mais bonitos e calmos. Sente logo a presença das diferenças de classe. Visita a favela da Brasilândia, lugar onde várias memórias de sua vida passada voltam à sua mente, com passos tímidos, e são depois apropriadas e utilizadas para a escrita de seu relato de vida. Christina obtém de um detetive (que contratou no Brasil) informações sobre sua mãe, que continua viva e mora em Minas Gerais. Finalmente, mãe e filha se reencontram, e a narradora descobre, quase ao mesmo tempo, que tem uma família e que sua mãe agora vive com ela, não é mais uma moradora de rua. São pessoas calorosas e simples, que ficam felizes em vê-la. A mãe da pequena Christiana não havia se esquecido dela e continua a amá-la. A filha fica, enfim, sabendo (pelas irmãs da mãe) as razões de ter ido para o orfanato e do "impedimento" de encontrarse com a mãe lá dentro. O fato é que sua mãe é - sempre foi - esquizofrênica. Só que agora está sendo tratada e vive com as irmãs, que também a buscaram e a reencontraram. Por intermédio da amiga tradutora, mãe e filha se entendem, choram e riem de alegria e fazem promessas de novos encontros. Christina, enfim, volta à Suécia mais tranquila. Resolve aproveitar seus conhecimentos, seus estudos, a profissão adquirida na vida sueca e o que ganha como empreendedora para criar uma fundação junto ao antigo orfanato onde viveu (hoje uma creche para crianças pobres). Dá à fundação seu nome brasileiro de origem: Coelho. Para cada exemplar vendido do livro que conta sua história de vida, uma parte será destinada à Coelho Growth Foundation, como explica uma página anexada após o final da narrativa. 
Tentamos aqui resumir as 255 páginas da obra Nunca deixe de acreditar (2017), mas, é claro, o fizemos de modo panorâmico. Evidentemente, ela é bem mais rica em dramas, risos, sustos e peripécias: mereceria um trabalho maior. A razão de ser desse panorama centra-se, sobretudo, no desejo de fazer com que o leitor conheça o material do qual destacamos alguns segmentos para neles lançar um olhar discursivo.

\section{Uma análise discursiva-argumentativa de alguns trechos do livro}

Dividiremos esta seção em duas partes complementares. A primeira tem como objetivo esclarecer alguns instrumentos metodológicos que aqui aplicaremos; a segunda mostra tal aplicação em segmentos da narrativa de vida que agora nos ocupa.

Como sempre fazemos, insistimos em deixar claro que a interpretação ou leitura que daremos a tais segmentos deve ser vista apenas como uma das muitas interpretações de uma analista do discurso (CHARAUDEAU, 2019, p. 34), dentre tantas outras possíveis. O fato é que existem escritas difíceis de ser classificadas e, dentre elas, a dos relatos/histórias/narrativas de vida. Estamos aí diante de um curioso gênero que mistura fatos reais com fatos vindos do imaginário (como já foi dito) formando uma espécie de escrita atemporal que pode ou não adotar características literárias ou tons históricossócio-filosóficos, abrindo-se a diversas interpretações.

\subsection{Algumas formas de captar a atenção do leitor/sujeito-interpretante}

Não negamos que o autor(a) ou sujeito-comunicante, por meio de seu sujeito-enunciador ou narrador(a) insere em sua narrativa de vida seu ponto de vista sobre o mundo que o rodeia ou rodeou. Há dois grandes modos de assim agir: em primeiro lugar, o(a) narrador(a), ao relembrar fatos dramáticos que viveu, pode utilizar uma escrita neutra, vazia, na qual seus sentimentos parecem ter sido silenciados. Segundo Amossy,

[...] o discurso testemunhal traz em sua base um paradoxo: se, por um lado, ele é totalmente fundamentado pela palavra do próprio sujeito-falante - ou seja, a autoridade que pode dizer: "eu estava lá", por outro lado, trata-se de um discurso que busca, por todos os meios possíveis, provar que é isento de subjetividade. (AMOSSY, 2007, p. 252) 
Notamos que tal fato ocorre na narrativa de certas passagens da vida de Christiana, como menina de rua. As cenas que vê e evoca são tão horríveis que ela entra no paradoxo da escrita testemunhal.

Em segundo lugar, quem narra pode também, ao evocar certas passagens, ali introduzir elementos linguageiros suscetíveis de emocionar o leitor, para fazê-lo entrar em seu relato, em seu mundo, para fazê-lo compreender melhor tudo o que foi vivido.

No âmbito de um discurso argumentado, como o do exemplo que agora nos interessa, notamos a presença desses dois tons narrativos: no primeiro caso, vemos surgir uma forma de "escrita branca", neutra. No segundo caso, deparamo-nos por vezes com relatos em que a emoção da narradora não consegue ser contida, o que gera a dramatização da palavra. Seja como for, tanto uma forma quanto outra visam estabelecer uma comunicação do euque-narra com o eu-que-lê, ou seja, uma troca interativa.

Para estudar a emoção ${ }^{3}$ dentro do último caso referido, seguiremos algumas noções retóricas propostas por Charaudeau (2000, 2007), que ele remaneja em função de sua análise do discurso. Lembramos que o objetivo principal desta análise é o de estudar a linguagem e as estratégias comunicativas que ocorrem (no mundo de papel) entre dois diferentes sujeitos: um sujeito-enunciador, ou seja, aquele que conta os fatos e quem os lê/interpreta (no caso, os diferentes leitores e a analista do discurso que agora escreve este artigo). Desse modo, consideramos as emoções a partir de certos "efeitos patêmicos", como propõe Charaudeau (2000, p. 140), que geram um certo número de tópicas opostas umas às outras. Por exemplo, a tópica da dor que se opõe à tópica da alegria, entre outras.

Para esse linguista, de certo modo, as emoções estão inseridas em "saberes de crença"4 , e tais saberes "são polarizados em torno de valores socialmente constituídos” (CHARAUDEAU, 2000, p. 131, Tradução: nossa). Na

\footnotetext{
3 Tomamos aqui “emoção" como sinônimo de "sentimento", lembrando, porém, que o sentimento em si não pode nem deve ser confundido com a expressão discursiva da emoção. Acreditamos que é melhor pensar no "sentimento" (em si) como um efeito que vai dar mais cor ou tornar mais vivo certos enunciados sustentados pela narradora que conta sua vida.

4 "Saberes de crença": eis um sintagma criado por Charaudeau. A ele preferimos, no entanto, um outro: "saberes partilhados", pois ele se insere mais facilmente no âmbito da análise do discurso que praticamos. As "crenças", a nosso ver, variam muito de uma pessoa para outra, de um lugar para outro.
} 
narrativa de vida de Christiana/Christina, notamos a utilização de termos tais como “dor”, “tristeza”, "lágrimas”, que provavelmente irão provocar certos efeitos no sujeito-interpretante, ou seja, levá-lo a aderir à voz que narra aspectos sensíveis de sua vida passada. Tal voz formula, pois, enunciados que, "ao circular na comunidade social, vão criar uma vasta rede de intertextos que se reagrupam para constituir os chamados imaginários sociodiscursivos" (CHARAUDEAU, 2000, p. 134, tradução nossa).

Em outras palavras: para que o sujeito-interpretante possa sentir os efeitos patêmicos é necessário que ele acompanhe ou "entre no jogo" da vozque-narra, quando ela deixa transparecer imaginários sociodiscursivos que envolvem e, de certo modo, sustentam seus enunciados, enunciados estes que, sem dúvida, carregam em si seu ponto de vista ou são impregnados por sua subjetividade.

Enfim, os chamados efeitos patêmicos podem ancorar-se em uma série de tópicas. Abordaremos aqui apenas dois "pares": a da alegria/dor e a da humanidade/barbaridade. Isso dito, passemos à segunda parte da seção, na qual transcrevemos alguns fragmentos da narrativa de vida de Nunca deixe de acreditar, para verificar, mais de perto, certos elementos desse discurso argumentante.

\subsection{Análises ou leituras de trechos do relato de vida de Christiana}

Começamos com dois fragmentos que, acreditamos, contêm indícios da "escrita branca", que leva (textualmente) a narradora a falar assumindo uma certa distância de algumas cenas deploráveis de seu mundo pobre:

(i) Eu estava sentada, de pernas cruzadas e encostada a um barraco em frente ao dela [o de uma menina que tinha entre sete e nove anos de idade, suja, desgrenhada, com um vestido vermelho sujo e grande demais para ela], esperando por Camile. Foi quando um homem abriu a porta, logo atrás da menina. Ele saiu só de cuecas e parecia embriagado. Olhou para a garota, a pegou pelos cabelos, arrancando-a da cadeira, e a empurrou para dentro do barraco. Ela não gritou nem chorou. Parecia estar acostumada a ser tratada daquela maneira. (RICKHARDSSON, 2017, p. 62-63)

(ii) Os nossos dias eram quase sempre iguais. Ficava claro, acordávamos, o estômago roncava e as lojas abriam suas portas. Muitas pessoas passavam andando, outras iam de carro, grande parte delas estava a caminho do trabalho, outras nem sabiam para onde estavam indo. [...]. Mais tarde, durante o dia, 
ficávamos com fome novamente e as pessoas um pouco lentas, um pouco cansadas. A noite chegava, escurecia e nós nos deitávamos onde havia lugar... (p. 73)

Os dois casos acima transcritos provêm de um discurso testemunhal. Tais discursos, como foi dito, mostram um lado paradoxal (AMOSSY, 2007, p. 252), ou seja, são sustentados por um sujeito-falante (no caso, a narradora Christiana/Christina) que tem autoridade para dizer "eu vi tudo, eu estava lá", mas que parece colar aos seus ditos um sentimento de profundo cansaço, desilusão. Logo, tanto (i) quanto (ii) parecem ter sido construídos em função de um desejo de mostrar o desencanto da narradora que, de tão habituada a presenciar cenas tristes, já nem sente mais nada quando as vê. Em termos discursivos, isso se traduz por meio de enunciados que parecem ser isentos de subjetividade.

Assim, em (i) a narradora descreve uma cena "normal" na favela, onde meninas são abusadas por homens rudes e bêbados sem que ninguém se espante com o fato ou faça algo para detê-lo. A menina que é arrastada para dentro do barraco é um ser que se tornou transparente para o mundo - pouco importa o que lhe sucede! Christiana, que vê tudo (para, muitos anos depois, transpor esse fato para seus escritos de vida), tenta encarar essa realidade da forma mais neutra possível. Mas, para obter esse efeito ela faz uso de “pequenas percepções reunidas" (RANCIÈRE, 2001, p. 94). O vestido da garota objeto-sexual é grande demais, mas tem a cor vermelha. Ela tem cabelos, mas eles são desgrenhados. Ela não está morta, mas não grita nem chora. Já deixou de ter vontade própria há muito tempo, apesar de tão jovem. É um "fantasma", como diria a narradora, temor que a perseguiu durante a infância passada nas ruas. A menina de roupa vermelha aparece, então, como um exemplo ao contrário para a narradora, que, pelo visto, dela nunca se esqueceu.

É preciso notar que Christiana, que assiste a cena, não julga nem condena ninguém. Ela se apaga como narradora para melhor descrever o indizível, aquilo que ninguém deveria ver, aquilo que não poderia acontecer na vida de nenhuma criança do mundo. 
Em (ii) novamente encontramos a presença da subjetiva neutralidade ${ }^{5}$ que, nesse ponto do relato resulta desse tom "branco" que comanda a narrativa. Estamos aí também diante de outra descrição de um dos muitos dias da menina de rua que mais tarde tornar-se-á a narradora de sua história. No caso, ela fala do seu cotidiano, junto à sua amiga Camile, de suas vidas como se fossem pequenos animais que erram pela floresta, sem abrigo, sem família, procurando apenas matar sua fome. Dormem onde podem, levantam-se e vão procurar comida. Dias, noites, dormir, acordar, procurar comida. Pronto. Mais nada. Embora esse seja o grande medo da Christiana brasileira, (ii) já parece conter uma narradora desencarnada de qualquer identidade, um ser despersonalizado.

Transcrevemos, a seguir, mais quatro segmentos em que ressaltaremos, em vez da "escrita branca", duas duplas de tópicas, fruto dos já chamados efeitos patêmicos, que tentam expressar emoções pela palavra escrita.

(iii) - Aqui está a sua bola, lindinha! - Ele deu risada antes de sair dali acompanhado pelo amigo. Fiquei com o rosto vermelho, com uma sensação de felicidade em mim.[...] Alguns momentos da vida são cheios de alegria. Aquele instante em que brincávamos e o garoto disse que eu era bonita foi um desses momentos para guardar na memória. (RICKHARDSSON, 2017, p. 57)

(iii') Nunca mais veria Camile novamente, ela nunca mais me abraçaria ali debaixo de nossa escada. Nunca mais ouviria a sua linda voz e nem as suas histórias maravilhosas. O que eu ia fazer? Não queria viver sem ela. Senti uma dor infinita dentro do meu peito. Não conseguia respirar, tinha algo errado com o meu coração. Era como se, de repente, eu já não soubesse como respirar. Doía tanto, como se fossem mil facas me cortando e tudo caiu na escuridão... (p. 81)

(iv) Mamãe foi até a estante de livros e pegou um deles. Começou a folhear e acabou encontrando o que buscava. Colocou o livro aberto sobre a escrivaninha, mostrando-me uma ilustração do que seria o universo. A ilustração era bonita e eu nunca havia visto algo parecido com aquilo antes, com exceção de meu sonho na noite anterior. Era a primeira vez que via o universo [...] Mamãe e eu ficamos ali no escritório, conversando, por bastante tempo, ou melhor tentando nos comunicar. Estava indo melhor do que eu havia esperado e conseguíamos nos entender com poucas palavras. (p. 182)

(iv') Continuei a procurar Camile com o olhar e a vi ao lado da menina. Ela também parecia estar com medo, não parava de olhar em volta, como se procurasse algo ou alguém. [...] Os homens se posicionaram a uma boa distância

\footnotetext{
${ }^{5}$ A "escrita branca" nada mais é que um estilo de escrita. Logo, assumi-la ou não depende do desejo de quem narra. Em suma, a neutralidade desse estilo é comandada pela subjetividade de quem assume a escrita.
} 
das crianças, algumas delas choravam e outras gritavam.[...] Vi que alguma coisa esquisita aconteceu na testa dela, lembro que enquanto seu corpo caía no chão da maneira mais bizarra possível, a minha mão direita subiu até meus lábios, sufocando o grito que ficou preso na minha garganta. A última coisa que ouvi foi o tiro. (p. 79)

Consideramos os excertos (iii) e (iii') como tópicas de alegria versus dor. Escolhemos tais tópicas pois elas se repetem em toda a narrativa de vida de Christiana/Christina. As pequenas alegrias da infância da menina de rua relembradas e transcritas por seu duplo "eu”, ou seja, ela mesma, mas já adulta e sob outra identidade. Em seu todo, a narrativa assumida por Christina Rickhardsson traduz a voz de uma mulher adulta que já passou pela mudança de país e de uma classe social para outra, completamente diferente. No entanto, a voz da criança pobre ecoa ainda na voz da adulta. Como afirma Jaquet (2015) ao apresentar o neologismo "transclasse":

O prefixo "trans", nesse caso, não marca somente a ultrapassagem ou a ascensão, mas um movimento de transição, de passagem para o outro lado. Ele deve ser tomado como sinônimo da palavra latina trans, que significa "do outro lado", e descreve o trânsito entre duas classes. (JAQUET, 2015, p. 13-14, tradução nossa).

Assim, a voz dessa transclasse - cuja passagem se opera "por obra do destino" 6 - fala de si mesma, como ela é agora, mas também fala pela outra que ela já foi. No domínio da narratividade estamos diante da encenação escrita ${ }^{7}$ de uma narrativa de vida que reúne duas épocas, duas vozes e dois seres de papel em diferentes idades e condições de vida. Tais seres são tão diversos um do outro que não podemos deixar de ver no relato, a presença da polifonia, pois, a voz da menina que não existe mais vai ser absorvida pela voz da mulher adulta. Sem dúvida, no domínio da narratividade, tal traço pode funcionar como uma estratégia discursiva de captação do leitor.

No segmento (iii) a narradora esforça-se para transmitir uma sensação de profunda alegria que sentiu, em sua infância pobre. Devemos contextualizar tal segmento para melhor compreender a emoção ou o sentimento de alegria que a envolve: a menina estava com sua amiga Camile

\footnotetext{
6 "Por obra do destino": tal expressão deve ser considerada apenas como uma metáfora. Na verdade, não dispomos de elementos para explicar quais as razões que levaram o casal sueco a vir ao Brasil e a justamente, escolher Christiana e seu irmão como crianças para adotar, entre as outras que havia no orfanato.

${ }^{7}$ Tal encenação, lembramos, é própria de quase todas as narrativas de vida.
} 
em um lixão, revirando-o para ver se ali encontrava algo que pudesse ter alguma utilidade para elas. Vemos, no caso, essa busca ligada à procura de um elemento lúdico, de algo que trouxesse a alegria da descoberta às meninas. Uma delas acaba por encontrar uma bola, e isso já é uma festa. Começam a chutar a bola. Essa movimentação inabitual é logo percebida por alguns garotos mais velhos que ali estavam. Um deles toma a bola das meninas, e seu grupo passa a jogá-la, para grande indignação delas, sobretudo, de Christiana, que reivindica a posse do brinquedo. Enfim, cansados de jogar, os garotos resolvem partir, e um deles joga a bola de volta para Christiana. Nesse momento, ele a chama de "lindinha". Ora, para alguém que se considerava inferior e feia como ela, esse "lindinha" soa como o maior elogio do mundo. Ela fica vermelha e feliz: vive em alguns segundos uma das maiores alegrias de sua vida, algo tão forte que nunca desapareceu de suas memórias, mesmo depois de adulta.

Há outros momentos em que a alegria aparece, mas ela é narrada por meio de expressões como "fiquei muito feliz", "foi bom", ou outras do gênero. O trecho (iii), no entanto, fala de uma sensação fora do comum, algo bom que aqueceu o rosto de Christiana, algo que sempre guardou consigo. No que diz respeito ao uso do léxico, a palavra "linda" colocada no diminutivo soa como uma carícia, adquire uma conotação de verdade. "Fiquei com o rosto vermelho, com uma sensação de felicidade em mim" diz a menina. O uso de "rosto vermelho", em vez do verbo "corar", é importante. Se a narradora escrevesse "ela sentiu que corava" de modo mais literário, haveria somente a descrição da sensação de felicidade/alegria; o uso do coloquial "fiquei com o rosto vermelho" dá um impacto maior à noção de bem-estar que invade a menina. Em nenhuma outra parte da narrativa ela se diz bonita. Só naquele curto instante sente a alegria de ser vista de modo positivo pelo outro.

A situação ou a tópica oposta a (iii), que chamamos de (iii') está ligada ao sentimento de dor, angústia, perda. Tais tópicas são uma constante na vida da menina e na narrativa. Escolhemos a que fala da morte de sua melhor amiga, Camile, e o momento seguinte a essa morte, no qual a dor vem inundar e sufocar completamente Christiana. Em (iii') deparamo-nos com uma construção patêmica que é mais evidente que a de (iii). Notamos a presença da figura da repetição que anuncia as duas qualidades ou alegrias de vida que foram embora com Camile: o primeiro "nunca mais" está ligado à voz de 
Camile, às histórias que ela inventava e contava, que eram realmente belas, como mostram outras páginas do livro. O segundo "nunca mais" indica a perda para Christiana de uma demonstração física de calor, carinho e afeto: o sentimento de ser abraçada por alguém que lhe queria bem.

Aparece aí também uma pergunta retórica: “O que eu ia fazer?”. Pois ela sabia o que iria se passar em sua vida sem a presença de Camile: seria ainda mais infeliz, mais sozinha. Outro ponto que deve ser notado é o do desejo de morte que vem com a dor da perda. A dor de Christiana, até então espiritual, transmite-se fisicamente para seu corpo: "Não conseguia respirar, tinha algo errado com o meu coração. Era como se, de repente, eu já não soubesse como respirar. Doía tanto, como se fossem mil facas me cortando e tudo caiu na escuridão..." A dor é tão forte que a menina deve ter contido sua respiração automaticamente, até desmaiar. Dor espiritual e dor física se unem nesse fragmento.

Prosseguindo, escolhemos os segmentos (iv) e (iv') para ilustrar duas outras tópicas que também percorrem os relatos de vida em tela: os que refletem sentimentos de humanidade e os que falam sobre a barbárie ou a desumanidade.

O efeito que a bondade e a calma da mãe adotiva de Christiana têm sobre ela nos foram transmitidos no excerto (iv). É preciso dizer que a menina já iniciou - mesmo ainda não estando totalmente consciente disso - a sua caminhada de transclasse, que a leva à transição de uma classe social miserável para outra: a classe média em um país mais humano e civilizado que o seu. (iv) aparece depois de um sonho de Christiana, em sua nova casa sueca, que se transforma em pesadelo. Ela sonha que está voando/viajando pelo espaço e pode ver o mundo todo. E, de repente, se vê diante de Deus. Christiana havia sido criada no respeito ao Deus da religião católica. No sonho, Deus a acolhe bem para depois expulsá-la, como se ela tivesse cometido um grande pecado. A queda brusca do pesadelo faz a menina gritar e ser amparada por Lili-Ann, sua mãe adotiva. Esta, no dia seguinte, em uma tentativa de acalmar a menina, a conduz ao escritório da casa, onde lhe mostra um livro sobre a terra e os planetas. Assim agindo, Lili-Ann demonstra sua humanidade face à desordem mental da filha adotiva. A sensação de paz e de estar em um mundo harmonioso é mostrada à menina de forma visual: Lili- 
Ann escolhe uma obra que corresponde ao real do que Christiana sonhara. É um ato humano que a acalma: "A ilustração era bonita e eu nunca havia visto algo parecido com aquilo antes, com exceção de meu sonho na noite anterior. Era a primeira vez que via o universo", diz ela. A sensação de paz e de primeiro reencontro com uma bela realidade envolvem essas palavras. E é o ato humano da mãe sueca que faz a menina descobrir que nem tudo seria assim tão mau no novo país. A parte final do excerto é submersa em um desejo calmo de comunicação: "Mamãe e eu ficamos ali no escritório, conversando, por bastante tempo, ou melhor tentando nos comunicar. Estava indo melhor do que eu havia esperado e conseguíamos nos entender com poucas palavras."

Acreditamos que (iv) é um símbolo dessa nova e tranquila forma de humanidade, até então não habitual na vida de Christiana, sobretudo no orfanato onde vivia e nas ruas de São Paulo. Note-se que a palavra "humanidade" não aparece, mas ela atravessa o excerto e se reflete, sobretudo, na tranquila interação entre duas pessoas completamente diferentes.

Em contraposição a isso, (iv') vem mostrar a desumanidade à qual são submetidas as crianças que vivem nas ruas. Para nós, essa é uma das cenas mais cruéis que o relato de vida desvela. Alguns homens armados, sem dúvida de uma milícia, percorriam as ruas de São Paulo adormecida à cata de crianças pobres... para eliminá-las, para limpar a cidade daqueles "ratos", como são chamadas pela classe dominante.

O excerto que transcrevemos conta o final de uma perseguição de um ou dois desses homens que queriam incluir Camile e Christiana no grupo de "ratos" a ser abatido com tiros. Conseguindo escapar (mas Camile não), Christiana volta e, escondida, assiste ao assassinato de sua amiga. Esse trecho da narrativa talvez pudesse ser considerado, em suas três primeiras linhas, como o relato testemunhal de alguém que tudo viu, que estava lá no momento da tragédia. E que tenta descrevê-la de forma neutra, usando a "escrita branca". Mas essa desaparece a partir do momento em que o "eu" toma a palavra: "Vi que alguma coisa esquisita aconteceu na testa dela", afirma Christiana. A desumanidade do ato é tanta que ele surpreende a menina, que enxerga apenas "uma coisa esquisita", em vez de uma mancha 
de sangue, um buraco na testa provocado pela bala de revólver do algoz noturno.

A forma como Christiana descreve a trajetória do corpo de Camile até o chão, a sua queda, provém de uma descrição subjetiva, individual. A emoção que tal crueldade cometida contra uma criança indefesa provoca é grande: "seu corpo [o de Camile] caía no chão da maneira mais bizarra possível, a minha mão direita subiu até meus lábios, sufocando o grito”.

A narradora transcreve aqui o ato cruel e o silêncio que corta o som das vozes de Camile e Christiana. Só após a queda da amiga morta, Christiana ouve um som: o do tiro. A narrativa procede por saltos para melhor exprimir o clarão do tiro e a emoção que a descrição da cena provoca. O efeito patêmico que a percorre tem um objetivo: fazer com que o leitor, sentado confortavelmente em sua cadeira, lendo o livro de Rickhardsson, sinta-se pelos menos incomodado em sua tranquilidade.

Os efeitos patêmicos funcionarão mediante três condições: (1) a existência de um dispositivo de comunicação favorável à eclosão de tais efeitos; (2) a existência de um campo temático no qual os acontecimentos ali reunidos sejam propícios à aparição de um universo ligado à patemização e sua organização em tópicas; (3) a existência de um espaço de estratégias que se abra para tais situações patemizantes (CHARAUDEAU, 2010, p. 40; REIS, 2016, p. 144-147).

Todas as condições são cumpridas não apenas pelos excertos (iv) e (iv'), mas, de modo geral, em grande parte da narrativa comandada por Rickhardsson e sua narradora. Existe no livro Nunca deixe de acreditar um dispositivo de comunicação atuante, em que um "eu" (desdobrado) fala a um "tu". Nele, há um campo temático - a vida e a mudança de vida de uma criança de rua, que são o fulcro maior da narrativa. Esta, por sua vez, se constrói por meio de estratégias comunicativas, sobretudo, as de captação do leitor. Ou, em outros termos, a questão de "como tocar o outro, fazê-lo sentir o que passei?" parece-nos ser um dos objetivos dessa narrativa de vida. Em alguns pontos é possível nela ver "um processo de dramatização que consiste em provocar a adesão passional do outro, atingindo suas pulsões emocionais" (CHARAUDEAU, 2007, p. 245). 
A patemia presente nos fragmentos aqui destacados para representar as tópicas de alegria/dor e humanidade/ barbárie mostram (ainda que por vezes nas entrelinhas e dependendo do contexto que as envolve) as intenções da autora que, por meio da voz de sua narradora - voz essa duplicada em voz infantil e voz adulta - buscou transmitir, com sua escrita, certas emoções em seus leitores ou, em linguagem semiolinguística, em seus sujeitosinterpretantes. Aliás, o campo temático e testemunhal da narrativa de vida mostra-se favorável tanto para a instalação da patemização quanto para a presença da escrita "branca".

\section{Considerações finais}

Quisemos aqui mostrar alguns momentos da vida de uma transclasse, na sua infância e na sua idade adulta, pois foi dentro dessa última que ela organizou sua narrativa e operou um trabalho que reuniu as vozes/identidades de Christiana Mara Coelho, menina brasileira criada nas ruas, e de Christina Rickhardsson, empreendedora sueca de classe média.

Sabemos que o caminho percorrido por essa transclasse apresenta diferenças em relação a outros caminhos, de outros transclasses. Poder-se-ia mesmo contestar e afirmar que a passagem de uma classe para outra, no caso desta narrativa de vida, não se operou pela própria vontade de Christiana/Christina, mas, simplesmente porque entre tantas outras crianças do orfanato, ela foi escolhida como filha adotiva do simpático casal sueco, que Ihe proporcionou uma vida digna em seu país. A razão desse movimento de transição continua então misteriosa já que não dispomos de maiores dados sobre os pais adotivos da narradora e sobre as razões que os levaram da Suécia ao Brasil para adotar um casal de crianças.

Christiana era uma menina de rua recolhida em um orfanato de crianças pobres e só podia obedecer ao que decidiam sobre sua vida, poderá o leitor argumentar. Logo, se houve mudança foi porque outras pessoas decidiram por ela.

No entanto, há outra parte que deve ser levada em consideração: a menina era uma guerreira, e isso se nota em seus escritos. Ela lutava - como podia - por seus direitos e por mais justiça, não hesitando em aplicá-la com seus métodos (os próprios punhos) quando era necessário. Viveu nas ruas e, 
depois, em um orfanato, abandonada a si mesma e aos seus sonhos e pensamentos até os 8 anos. No entanto, isso não apagou sua natural força de caráter; ao contrário, veio reforçá-la. A menina Christiana pareceu-nos ser uma dessas criaturas que tentam aproveitar o melhor de tudo que lhes acontece e daí tirar alguma lição. Seu enorme afeto pela mãe biológica, que nunca diminuiu com o tempo, prova isso: sua mãe era esquizofrênica, por inúmeras vezes (sobretudo em São Paulo) a abandonava à sua sorte, "ao Deus dará". Porém, nas vezes em que voltava, transmitia muito amor à menina.

A transição de vida de Christiana não foi por ela totalmente acolhida como um presente, pelo menos em seu início. À medida em que foi crescendo, ela foi se habituando ao seu novo país e, certamente, recebendo as boas influências dele. Foi assim que pôde voltar ao Brasil para acalmar as angústias que ainda lhe pesavam na consciência, a sensação de culpa que sentia por certas ações e, sobretudo por pensar que, no fundo, havia abandonado a mãe. Sabia bem - pois vê-se que sempre foi uma pessoa inteligente - que não era bem assim, que ela não tinha culpa de nada, mas os sentimentos destrutivos não escolhem nem hora nem a lucidez dos seres humanos para atacar. Esse movimento de volta às origens é bem comum nos transclasses, de modo geral, pelo que já notamos em nossos estudos sobre o assunto.

Gostaríamos de justificar também o fato de termos escolhido poucos trechos para analisar a presença da argumentatividade no discurso da narradora. O espaço para um artigo deve ser respeitado. Ressaltamos, no entanto, que a obra/narrativa de vida Nunca deixe de acreditar é muito rica, discursiva e emocionalmente falando. Foi muito bem construída, ao alternar mergulhos no passado com a volta à superfície do presente da escritora/narradora de vida. Ela se abre, assim, a várias interpretações.

Seja como for, a análise do discurso, ao enfocar tanto a parte explícita quanto a parte implícita dos escritos da autora/narradora pode contribuir para estudos de relatos que implicam o discurso testemunhal, discurso que explica muitas coisas, mas também as denuncia, na esperança de ser ouvido/compreendido pelo outro, que pode, desse modo, agir para ajudar a modificar situações tristes como, por exemplo, a das crianças que crescem na rua. 


\section{Referências}

AMOSSY, Ruth. A Espécie Humana, de Robert Antelme ou as modalidades argumentativas do discurso testemunhal. Tradução: Ida Lucia Machado. In: MACHADO, I. L. et al. (org.). As emoções no discurso. Rio de Janeiro: Lucerna, 2007. p. 252-271.

BAKHTINE, Mikhail. Problèmes da la poétique de Dostoiévski. Paris: Seuil, 1970.

CHARAUDEAU, Patrick. Langage et discours. Paris: Hachette, 1983.

. Grammaire du sens et de l'expression. Paris: Hachette, 1992.

- La pathémisation à la télévision comme stratégie d'authenticité. In : PLANTIN, C. (Dir.). Les émotions dans les interactions. Lyon: Presses Universitaires de Lyon, 2000.

. Pathos e discurso político. Tradução: Emília Mendes. In: MACHADO, I. L. et al. (org.). As emoções no discurso. Rio de Janeiro: Lucerna, 2007. p. 240-251.

. Compréhension et interprétation. Interrogations autour de deux modes d'appréhension du sens dans les sciences du langage. In: ACHARD-BAYLE, G. et al. (Dir.). Les sciences du langage et la question de l'interprétation (aujourd'hui). Paris: Éditions Lambert-Lucas, 2019.

GRÁCIO, Rui Alexandre. A argumentação na interação. Coimbra: Grácio Editora, 2016.

JAQUET, Chantal. Les transclasses ou la non-reproduction. 3.éd. Paris: P.U.F., 2015.

MACHADO, Ida Lucia. Reflexões sobre uma corrente de análise do discurso e sua aplicação em narrativas de vida. Coimbra: Grácio Editora, 2016.

. Quem escrevia sobre as classes empobrecidas no Brasil antes que a pesquisa em ciências humanas e sociais se interessasse por suas histórias de vida? In: ARAÚJO, C. L.; RESENDE, V. M. (org.). Discurso e pobreza. Abordagens sobre classe, raça, gênero e território. Campinas: Pontes, 2018. p. 89-110.

RANCIÈRE, Jacques. S'il y a de l'irreprésentable. In: NANCY, J. L. (org.). Le genre humain numéro 36. L'Art et la mémoire des camps. Représenter, exterminer. Paris: Seuil, 2001. p. 81-102.

REIS, Alcione Aparecida Roque. A trilogia "Nossos Antepassados" de Italo Calvino: uma análise discursiva. 2016. Tese (Doutorado em Estudos da Linguagem) - Faculdade de Letras, Universidade Federal de Minas Gerais, Belo Horizonte, 2016.

RICKHARDSSON, Christina. Nunca deixe de acreditar. Tradução: Fernanda S. Äkesson. Ribeirão Preto: Novas Ideias, 2017. 


\section{Forma de citação sugerida}

MACHADO, Ida Lucia. As duas vidas de uma transclasse. EID\&A - Revista Eletrônica de Estudos Integrados em Discurso e Argumentação, Ilhéus, n. 19, v. 2, p. 71-92, dez.2019. DOI 10.17648/eidea-19-v2-2436. 